\title{
Aussi un devoir médical
}

\section{Jean-Jacques Fasnacht}

Dr méd., président PSR/IPPNW Suisse

Les bruits de bottes nucléaires ne peuvent être ignorés tant ils sont inquiétants. Les provocations nord-coréennes testent les limites de la tolérance internationale et américaine. Le régime nord-coréen et le président des Etats-Unis rivalisent ouvertement en rhétorique guerrière, alors que l'Inde et le Pakistan, dans leur permanent face à face hostile, sont armés jusqu'aux dents pour un conflit nucléaire régional. La réduction du nombre des armes atomiques durant ces dernières années a été plus que largement compensée par la modernisation des arsenaux [1,2]. La question inquiétante est de savoir quels événements pourraient mettre en mouvement cette machine mortifère. La mauvaise manipulation d'un dispositif défensif [3] ou un conflit politique pourraient faire basculer l'équilibre instable de la terreur. Les effets désastreux des armes atomiques sont parfaitement connus [4, 5]: Hiroshima et Nagasaki. Rappelons que le respecté Marcel Junod, délégué suisse au CICR, a été le premier médecin étranger à être confronté aux horreurs d'une guerre nucléaire.

On connaît de mieux en mieux les effets du rayonnement ionisant, et il est démontré qu'en cas de conflit nucléaire toute forme d'aide médicale serait désespérément dépassée [6]. Il est également démontré scientifiquement qu'une guerre nucléaire, même régionale, au- rait des répercussions globales sur le climat, avec chute de la production agricole et famines [7, 8].

Etant donné ces réalités effroyables, et conformément à nos obligations de médecins, nous exigeons que les armes atomiques soient définitivement bannies. C'est dans cet esprit que les sociétés médicales nationales, réunies à Moscou en 2015 au sein de la WMA (World Medical Association), ont signé une déclaration qui non seulement condamne l'usage, la production et la détention d'armes atomiques (Nuclear Prohibition Treaty), mais appelle les sociétés nationales à agir au-

\section{La mauvaise manipulation d'un dispositif défensif ou un conflit politique pourraient faire basculer l'équilibre instable de la terreur.}

près de leurs gouvernements pour une mise hors la loi de ces armes (cf. encadré). Ceci a certainement contribué à ce que 122 pays aient voté le 7 juillet 2017 à l'ONU pour un traité d'interdiction des armes atomiques [9], traité qui devra être signé le 20 septembre 2017. La Suisse s'est jointe, avec quelques réserves. En tant que médecins suisses, astreints à nos règles éthiques et conformément à la déclaration de la WMA, nous exigeons que la Suisse soutienne et signe ce traité de l'ONU. Même si les puissances nucléaires ne sont pas

\section{WMA STATEMENT ON NUCLEAR WEAPONS, amended by the 66th WMA General Assembly, Moscow, Russia, October 2015}

The WMA Declarations of Geneva, of Helsinki andTokyo make clear the duties and responsibilities of the medical profession to safeguard the health of the patient and to consecrate itself to the service of humanity. The WMA considers that it has a duty to work for the elimination of nuclear weapons.

Therefore the WMA:

Condemns the development, testing, production, stockpiling, transfer, deployment, threat and use of nuclear weapons Requests all governments to refrain from development, testing, stockpiling, transfer, deployment, threat and use of nuclear weapons and work in good faith towards the eliminations of nuclear weapons

Advises all governments that even a limited nuclear war would bring about immense human suffering and substantial death toll together with catastrophic effects on earth's ecosystem, which could subsequently decrease the world's food supply and would put a significant portion of the world's population at risk of famine

Requests that all National Medical Associations join the WMA in supporting this Declaration, use available educational resources to educate general public and urge their respective governments to work towards the elimination of nuclear weapons

Requests all National Medical Associations to join the WMA in supporting this Declaration and urge their respective governments to work to ban and eliminate nuclear weapons. 


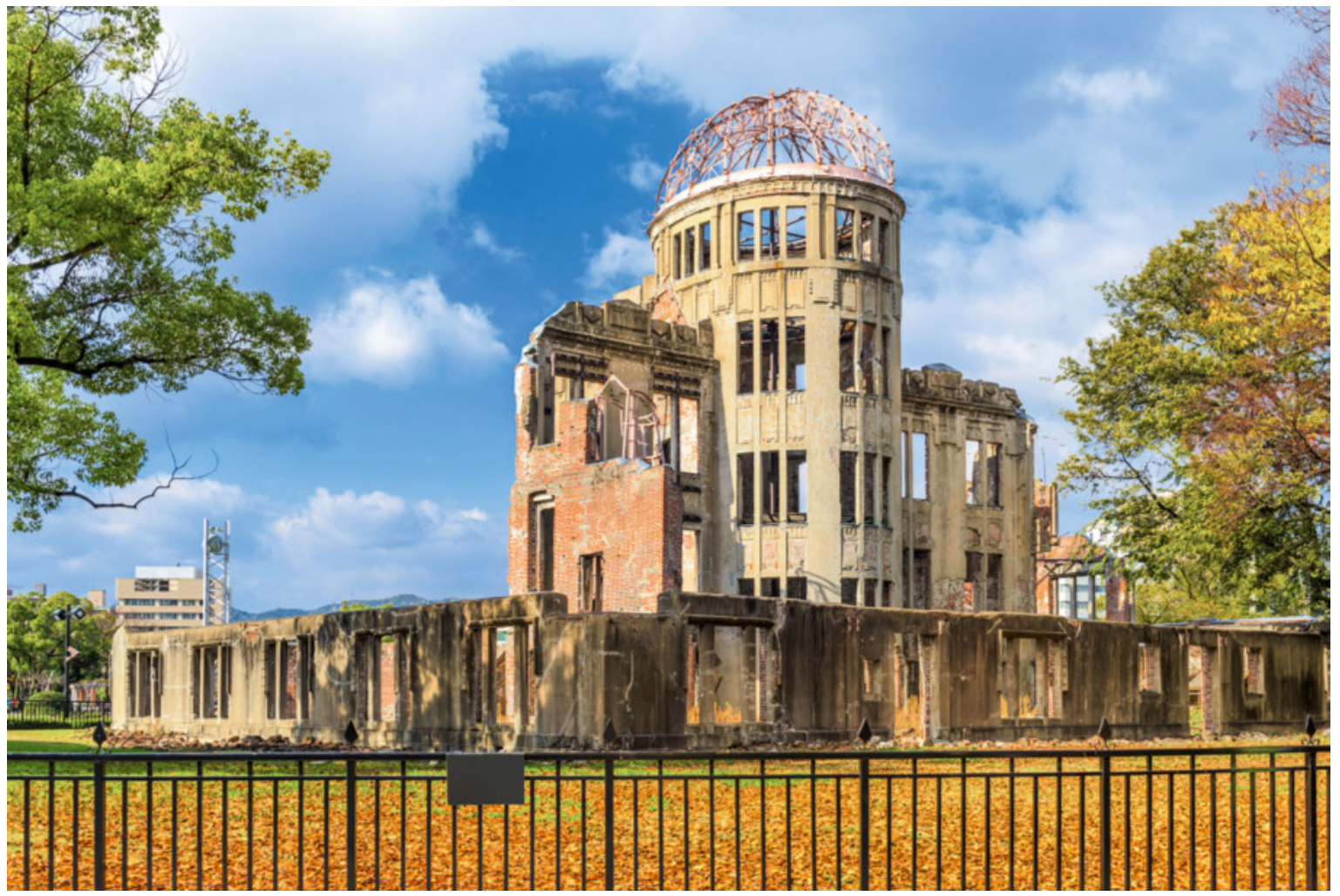

Le Mémorial de la Paix de Hiroshima.

encore prêtes à renoncer à leurs armes atomiques, ce traité à portée mondiale est un pas important en direction de l'élimination de ces armes de destruction massive, aux effets humanitaires désastreux.

\section{Une guerre nucléaire, même régionale, aurait des répercussions globales sur le climat.}

Ces thèmes seront abordés lors du congrès «Human Rights, Future Generations and Crimes in the Nuclear Age» [10].

PSR / IPPNW Suisse

Médecins pour une Respon-

sabilité Sociale / pour la

Prévention de la Guerre

Nucléaire

Bireggstrasse 36

CH-6003 Lucerne

sekretariat[at]ippnw.ch

\section{Références}

1 Kristensen H, Norris R. Status of World Nuclear Forces. Federation of American Scientist, 2016, http://fas.org/issues/ nuclearweapons/status-world-nuclear-forces/

2 Kristensen H. World Nuclear Weapon Modernization Programs http://fas.org/wp-content/uploads/2014/05/brief2015_NPT1a.pdf
3 Schlosser, Command and Control. Penguin Press, London, 2013. 4 World Health Organization, Effects of Nuclear War and Health and Health Service, 2nd ed. Geneva, 1987.

5 Institute of Medicine, The Medical Implications of Nuclear War, National Academy Press, Washington, 1986.

6 Helfand I, Forrow L, McCally M, Musil R. Projected US Casualties and Destruction of US Medical Services From Attacks by Russian Nuclear Forces. Medicine Global Survival 2001;7(2):68-76.

7 Robock A, Oman L, Stenchikov G, Toon O, Bardeen C, Turco R. Climatic consequences of regional nuclear conflicts. Atm Chem Phys 2007;7:2003-12.

8 Helfand I. Nuclear Famine: Two Billion People at Risk. International Physicians for the Prevention of Nuclear War, 2013, http:// www.ippnw.org/nuclear-famine.html

9 United Nations General Assembly: Treaty on the Prohibition of Nuclear Weapons, 2017, http://www.undocs.org/en/a/ conf.229/2017/L.3/Rev.1

10 Congrès 'Human Rights, Future Generations and Crimes in the Nuclear Age', Université de Bâle, 14-17.9.2017 (www.events-swissippnw.org), organisation PSR/IPPNW Suisse et SAFNA (Avocats suisses pour le désarmement nucléaire).

\section{Crédit photo}

(c) Sean Pavone | Dreamstime.com 